\title{
ECONOMIC VIABILITY OF ARABICA COFFEE IN THE STATE OF ESPÍRITO SANTO CONSIDERING MANUAL AND SEMI-MECHANIZED HARVEST
}

\author{
Edileuza Vital Galeano ${ }^{1}$, Cesar Abel Krohling ${ }^{2}$
}

(Received: March 26, 2019; accepted: May 20, 2019)

\begin{abstract}
Recent studies have shown that coffee production costs have been rising above inflation and that the activity has become less attractive to producers. One of the ways to try reducing costs is through the mechanization of activities. The objective of this study was to evaluate the production cost and economic viability of arabica coffee in the state of Espírito Santo, comparing manual and semi-mechanized harvest to different yield levels. For the feasibility analysis, the techniques of Net Present Value and Internal Rate of Return were used and the sensitivity analysis was used for risk assessment. The results show advantages of semi-mechanized harvest. At the level of 50 bags per hectare, the activity was profitable considering the interest rate of $8 \%$. In manual harvesting, the IRR is $8.3 \%$ and, in the semi-mechanized harvest, the IRR is $16 \%$. Producers must invest in higher yield levels with new technologies and mechanization to have greater return in the activity.
\end{abstract}

Index terms: Coffee cultivation, investment, modernization.

\section{VIABILIDADE ECONÔMICA DO CAFÉ ARÁBICA NO ESTADO DO ESPÍRITO SANTO CONSIDERANDO COLHEITA MANUAL E SEMIMECANIZADA}

RESUMO: Estudos recentes têm mostrado que os custos de produção de café estão subindo acima da inflação e que a atividade tem se tornado pouco atrativa para os produtores. Uma das maneiras de tentar reduzir custos é através da mecanização das atividades. Este trabalho teve como objetivo aferir os custos de produção e viabilidade econômica do café arábica no estado do Espírito Santo comparando a colheita manual e semimecanizada para diferentes níveis de produtividade. Para a análise de viabilidade foram utilizadas as técnicas de Valor Presente Líquido e Taxa Interna de Retorno. Os resultados evidenciam vantagens da opção pela colheita semimecanizada. No nível de 50 sacas por hectare a atividade se mostrou rentável considerando a taxa de juros de $8 \%$. Na colheita manual a TIR foi de $8,3 \%$ e na colheita semimecanizada a TIR foi de $16 \%$. Os produtores devem investir em níveis maiores de produtividade com novas tecnologias e mecanização para ter maior retorno na atividade.

Termos para indexação: Cafeicultura, investimento, modernização.

\section{INTRODUCTION}

Coffee cultivation continues to be the highlight of Brazilian agriculture (APARECIDO, ROLIM, SOUZA, 2015; AMARASINGHE et al., 2015; APARECIDO et al., 2016). In the state of Espírito Santo, coffee cultivation represented $36.2 \%$ of the Gross Value of farming production in 2016. Espírito Santo is the second largest national coffee producer, responsible for $20.1 \%$ of the national coffee production in 2017, with 9.3 million bags. Coffee comprised $18.4 \%$ of the State agribusiness exports in 2017 (GALEANO, 2017). According to data from the Ministry of Labor, formal jobs in coffee cultivation accounted for $23.3 \%$ of employment in farming in Espírito Santo in 2016 (MTE-RAIS, 2016).

Espírito Santo produces two varieties of coffee: arabica and conilon. Arabica is the predominant variety in the south of the state and conilon is predominant in the north. Arabica coffee production is present in 45 municipalities of Espírito Santo and represented $32 \%$ of the state coffee production in 2017 (LSPA-IBGE, 2017).

Since coffee is a perennial culture, it is subject to various risks such as climatic adversities, diseases and pests, as well as market and price risks (BARBOSA et al., 2012). With increasing competitiveness in the agricultural sector, the demand for research on production costs also increases and, regarding coffee, it is possible to mention the studies of Fernandes et al., 2013; Silva et al., 2013; Silva et al., 2014; Cunha et al., 2015; Cunha et al., 2016a and 2016b; Jasper et al., 2013; Lanna et al., 2012 as examples. According to Matiello et al., (2016) the analysis of costs, revenues and performance of coffee cultivation should be based on medium and long-term evaluations, carefully choosing the region for crop implementation. Currently, the cost of implementing a coffee crop is relatively high; thus, the producer must make a careful analysis in the decision making of the investment.

\footnotetext{
${ }^{1}$ Instituto Capixaba de Pesquisa/ INCAPER - Assistência Técnica e Extensão Rural - Rua Afonso Sarlo, 160 - Bento Ferreira 29.052-010 - Vitória - ES - edileuzagaleano@gmail.com

${ }^{2}$ Instituto Capixaba de Pesquisa/ INCAPER - Assistência Técnica e Extensão Rural - Av. Harthuer Haese, 124 sl 201 - Centro 29.255-000 - Marechal Floriano - ES- cesar.kro@incaper.es.gov.br
} 
This analysis, according to Matiello et al. (2016), includes: a) conjunctural and economic analysis, such as market conditions, supply and demand, prices, interest rates, exchange rate policy and agricultural policy; b) analysis of the property, on aptitude, infrastructure, administration and labor; c) analysis of crop management, the technological level, culture-related problems, yield and production costs. In addition, the costs of implementation, harvest and post-harvest should be planned as well (CUNHA et al, 2015; JASPER e SILVA, 2013; SANTOS et al., 2013, 2015 e 2017; MEJÍA et al., 2013).

A study by the National Supply Company (CONAB) showed that arabica coffee producers in the municipality of Venda Nova do Imigrante in Espírito Santo only had a positive margin in two of the nine years analyzed between 2012 and 2016 (the costs of implementing the crop were not considered). The study shows that costs rose above inflation (CONAB, 2017).

According to a study by Matiello (2018), coffee production costs increased in the last harvest seasons and reached the prices obtained in coffee sale, reducing the profitability of producers. As prices are determined by the market and the producer can do little to avoid further financial losses, a careful analysis of production costs should be performed periodically. The data collected by the Campo Futuro project, a partnership between the Federal University of Lavras and the National Confederation of Agriculture, showed that in the south of Minas Gerais, in the 2017 harvest, costs were respectively $\mathrm{R} \$ 450.00$ per bag, in the municipality of Santa Rita do Sapucai, and $\mathrm{R} \$ 462.00$, in the municipality of Guaxupé, considering the total operating costs. The increase from 2016 to 2017 was around $8.4 \%$. The cost estimate for the 2016 harvest showed that, for the production of 10 bags per hectare, the costs are around R\$ 600.00 per bag and, for 40 bags per hectare, costs fall to $\mathrm{R} \$ 300.00$ per bag (MATIELLO, 2018).

One of the ways to reduce costs in coffee harvesting has been mechanization, which can contribute to the reduction in human labor and increase labor productivity and the financial return of farmers (OLIVEIRA et al., 2007; SANTINATO et al., 2014; CUNHA et. al., 2016b; JASPER and SILVA, 2013). One of the great challenges for mechanized coffee harvesting comprises its feasibility and improvement in steep lands (CÁRDENAS et al., 2013; CÁRDENAS et al., 2015; SANTINATO, et al., 2016). Soil slope is an influencing factor on productivity for mechanical systems, and harvesters that work under such conditions suffer a decrease in operational efficiency and yield, due to a higher time demand during harvest (CUNHA et al., 2016b). For Lanna and Reis (2012), manual harvesting is infeasible, while mechanization has a lower cost and higher return rates. It is possible to assure that mechanical harvest for coffee trees yields greater cost reduction and an increase in productivity in relation to other systems, besides being economically viable (CUNHA et al., 2016b).

Considering the average production of arabica coffee in the state of Espírito Santo around 21 bags per hectare, which is below the national average (24.3 bags per hectare) (CONAB, 2018), it is important to evaluate the average production costs of arabica coffee in order to better guide the producer in their decision-making.

Coffee prices increased in 2016, reflecting lower production. The average price received by the arabica coffee producer reached a peak of $\mathrm{R} \$$ 475.43 in November 2016 and decreased to $\mathrm{R} \$$ 402.43 in December 2017 (INCAPER, 2017). In March 2018, the price received by the arabica coffee producer was around $\mathrm{R} \$ 380.00$ per bag, reflecting the expectation of a larger production. In addition to cost evaluation, the producer needs to create market strategies to improve decisionmaking in productive arrangements, as well as to be attentive to market trends (CHIPANSHI et al., 2015; PINTO et al., 2015; SANTOS, GOMES and GOMES, 2015).

The objective in this study was to estimate the cost of implantation and production of arabica coffee in the state of Espírito Santo and to verify the economic viability of the activity, comparing the manual and semi-mechanized harvest for different production levels.

The semi-mechanized harvesting system consists in the use of machines only in part of the execution of harvesting operations. In this system, tractor-driven machines perform coffee harvesting after manual stripping and branch cutting. This system has the potential to serve small, medium and large producers (SOUZA et al., 2017).

\section{MATERIAL AND METHODS}

For the development of this study, a survey of the technical coefficients indicated for the cultivation of arabica coffee was initially carried out, together with specialists in the activity. Subsequently, the average prices of the inputs and the average selling price practiced in the producing 
region were surveyed. All costs of inputs, labor, depreciation, cost of land and opportunity cost during the entire production cycle were considered. Production cost calculations were made for the following yield levels: 15, 20, 30, 40 and 50 bags per hectare in a rainfed crop. The survey was conducted in 2017.

The total cost consisted of explicit costs (inputs and labor) and implicit costs (crop depreciation, land cost and opportunity cost) (MANKIW, 2014; SANTOS et al, 2009). The operational cost expresses the relation of the cost and the capacity of work or production, allowing the rational use of the resources (PIACENTINI et al., 2012). Regarding the land, only its opportunity cost was considered, following the methodology described by COMPANHIA NACIONAL DE ABASTECIMENTO (2010), which estimates that the land remuneration rate is $3 \%$ of the average real selling price of the land. The average price of bare land of the region producing arabica coffee (CARNIELLI et al, 2017) was considered.

As for crop depreciation, according to Santos, Segatti and Marion (2009) and Crepaldi (2012), this cost should be considered for permanent crops, according to their production lifetime. For coffee cultivation, according to technical information gathered from producers and specialized technicians, production starts from the second year and reaches its maximum from the third year. According to the surveys, yield is considered good during 20 years of production from the third year, that is, a production lifetime of 20 years is considered for purposes of depreciation calculation (SANTOS et al, 2009).

For the purpose of analyzing the opportunity cost of resources allocated to the activity, an interest rate of $8 \%$ per year was considered, which would be close to the remuneration required for application in the financial market.

For the financial analysis, economic viability indicators were considered (GITMAN, 2010; ASSAF NETO; LIMA, 2014): Net Present Value (NPV) and Internal Rate of Return (IRR).

$$
\begin{gathered}
N P V=\sum_{t=1}^{n} \frac{R_{t}-C_{t}}{(1+i)^{t}}-I_{0} \\
O=\sum_{t=1}^{n} \frac{R_{t}-C_{t}}{(1+I R R)^{t}}-I_{0}
\end{gathered}
$$

In equations 1 and $2, \mathrm{NPV}=$ net present value, $\mathrm{R} \$$; $\mathrm{Rt}=$ revenue in each month, $\mathrm{R} \$ \mathrm{Ct}$ $=$ cost in each month; $\mathrm{I}_{0}=$ initial investment; $\mathrm{n}$ $=$ time of project analysis in years; $\mathrm{i}=$ minimum attractive rate of return (MARR); IRR = internal rate of return.

For the investment to be considered viable, the NPV should be positive, and the higher the NPV, the more attractive the investment. The IRR should be higher than the cost of capital or opportunity cost.

\section{RESULTS AND DISCUSSION}

The cost and economic viability for the production of arabica coffee at different yield levels were evaluated, considering manual and semi-mechanized harvest. In cost evaluation, many producers erroneously consider only the explicit costs, that is, those payments in which the producer perceives the monetary disbursements. However, many producers forget to account for costs which they do not physically cash out. This leads to an illusion that one is profiting from the activity.

The initial investment in the first year, considering only the inputs and labor, is $\mathrm{R} \$$ $10,554.73$ to produce 15 bags per hectare. Adding the depreciation costs of machinery and equipment, land cost and opportunity cost, the total investment in the first year is $\mathrm{R} \$ 12,199.40$. To produce 50 bags per hectare, costs with labor and inputs totaled $\mathrm{R} \$ 23,030.96$ and, including other costs, the total rises to $\mathrm{R} \$ 25,577.33$. In depreciation costs, only the costs related to the working hours of each of the machines and equipment in coffee production were included, since they are also used in other crops. Some costs, such as the cost of land and depreciation are fixed; therefore, for lower yield levels, such costs weigh relatively more for the producer. For a yield level of 15 bags, the cost of land represents $4 \%$ and, for a yield of 50 bags, the land represents only 1.9\% of the costs. Implicit costs are relatively higher for the producer who produces 15 bags per hectare, representing $12.9 \%$, while for a yield of 50 bags, implicit costs represent $10 \%$. As for the number of hours per machine, most of the time, what is spent to obtain a yield of 15, is also spent for a yield of 40 or 50 bags per hectare, as is the case of carrying fertilizer, mowing, spraying or even picking up the coffee in the countryside. A cart carries 60 bags but, if the yield is low and 15 bags or 50 bags are picked during the day, the machine time is the same, that is, the number of hours per machine is similar for the various yield levels. 
TABLE 1 - Initial investment (1st year) for the implantation of 1 ha of arabica coffee at different yield levels.

\begin{tabular}{lcccccccccc}
\hline $\begin{array}{l}\text { Specification / } \\
\text { Productivity levels } \\
\text { (bags / ha) }\end{array}$ & $\mathbf{1 5}$ & $\mathbf{\%}$ & $\mathbf{2 0}$ & $\mathbf{\%}$ & $\mathbf{3 0}$ & $\mathbf{\%}$ & $\mathbf{4 0}$ & $\mathbf{\%}$ & $\mathbf{5 0}$ & $\mathbf{\%}$ \\
\hline Inputs & $2,916.93$ & 24.1 & $3,536.46$ & 27.8 & $4,820.50$ & 27.8 & $5,801.98$ & 28.3 & $7,656.54$ & 29.9 \\
Labor & $7,637.80$ & 63.0 & $7,592.68$ & 59.6 & $10,584.40$ & 61.0 & $12,524.95$ & 61.1 & $15,374.43$ & 60.1 \\
Total direct costs & $10,554.73$ & 87.1 & $11,129.13$ & 87.4 & $15,404.90$ & 88.8 & $18,326,93$ & 89.3 & $23,030.96$ & 90.0 \\
Depreciation machines & 233.70 & 1.9 & 233.70 & 1.8 & 233.70 & 1.3 & 233.70 & 1.1 & 233.70 & 0.9 \\
Cost of land & 486.59 & 4.0 & 486.59 & 3.8 & 486.59 & 2.8 & 486.59 & 2.4 & 486.59 & 1.9 \\
Opportunity cost & 844.38 & 7.0 & 890.33 & 7.0 & $1,232.39$ & 7.1 & $1,466.15$ & 7.1 & $1,842.48$ & 7.2 \\
Total cost & $12,119.40$ & 100.0 & $12,739.76$ & 100.0 & $17,357.58$ & 100.0 & $20,513.38$ & 100.0 & $25,593.73100 .0$ \\
\hline
\end{tabular}

The initial investment values per hectare are considered high when compared with other alternatives of agricultural investment and, once it is a perennial crop, the producer must evaluate its costs with criteria.

In the second year of activity, the costs of inputs and labor are relatively lower, but there are other costs such as the establishment of the patio and granary, for example, as well as crop depreciation, which start to be accounted for when production starts. In the second year, the producer obtains a small harvest that varies from 5 to 20 bags, according to crop yield level. The obtained revenue helps minimize crop costs, but does not even cover the costs of the second year.

In the third year of production, yield is already at its highest level and the producer can make a comparative evaluation of the costs and revenue obtained. Graphs $1 \mathrm{~A}$ and $1 \mathrm{~B}$ show the total explicit and implicit costs and revenues obtained for the various yield levels. The total cost increases according to yield level and the average cost per bag decreases as yield level increases (Graphs $1 \mathrm{C}$ and 1D). If the producer considers only the explicit costs, they have the impression that they are having return (profit) with yield between 15 and 30 bags per hectare. However, when all the costs are considered, only from 30 bags a positive result in manual harvest is obtained.

In semi-mechanized harvesting, the cost of acquiring black plastic canvas, labor and machines is the same for producing 30, 40 and 50 bags per hectare. In this case, semi-mechanized harvesting becomes feasible only from 32 bags; while in manual harvesting, 30 bags are sufficient to pay for the costs. With a yield level of 15 bags, the producer will have an estimated loss of R $\$ 140.00$ per bag. With a yield level of 50 bags per hectare, the profit is estimated at $\mathrm{R} \$ 70.00$ per bag.
Table 2 presents the costs of the third year of activity for the various yield levels in manual and semi-mechanized harvesting. Although the annual costs indicate that, from 30 bags, the producer can obtain a return with manual harvest, it is still necessary to conduct an economic viability study considering the value of the initial investment, that is, the cost of implementing the crop. Thus, the producer must calculate the net present value and the internal rate of return, considering the 20 years of crop production.

From the data collected, there is evidence that the activity only presents viability at the level of 50 bags per hectare, for both manual and semimechanized harvest. In manual harvesting, the IRR is $8.3 \%$ and is very close to the opportunity cost adopted. In the semi-mechanized harvest, the IRR is $16 \%$ and the net present value is $\mathrm{R} \$$ $21,411.12$, which represents a net profit of $\mathrm{R} \$$ 428.22 per bag during crop life cycle.

The producer must have this notion of how much they are losing, that is, if they have been decapitalizing over the years for insisting on maintaining a crop with low yield levels. Some producers are able to produce high quality coffee and get a higher price for their production, which makes the activity viable. However, most producers end up selling their product at the average market price and can barely pay for the costs.

As an evaluation, the net present value and the internal rate of return were also calculated with different levels of interest rates, since some of the producers obtain financing with subsidized interest rates. Rates of $4 \%, 6 \%, 8 \%$ and $10 \%$ were considered.

The results indicate that the producer can return from 40 sacks per hectare in manual harvest, and at the levels of 30 and 40 sacks with semi-mechanized harvest, provided that they have subsidized credit. 
A

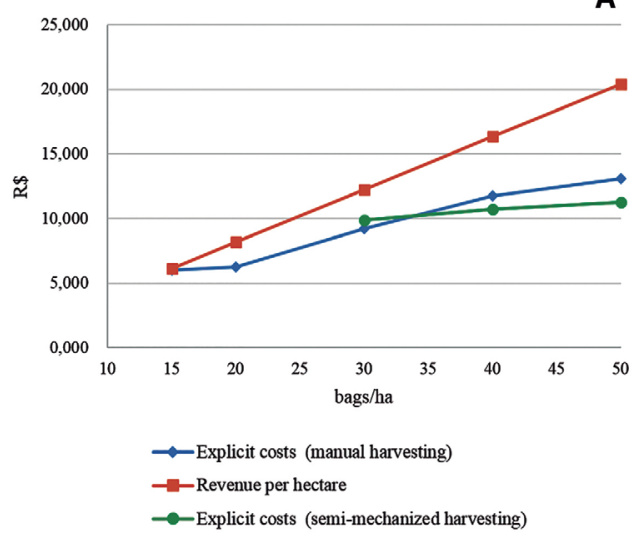

C

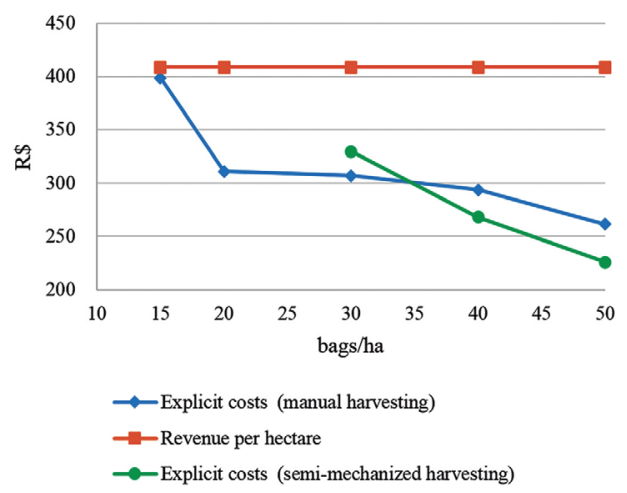

B

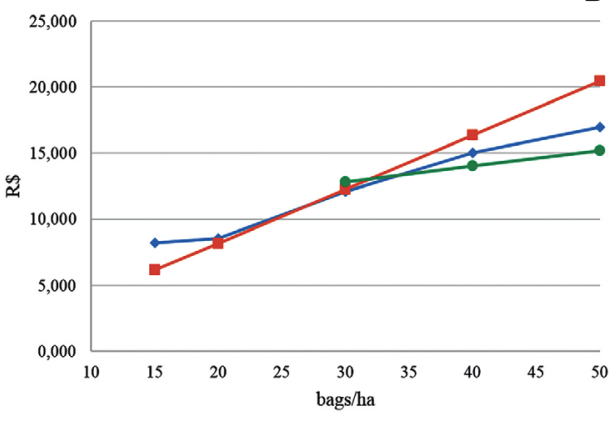

$\rightarrow$ Explicit costs + implicit costs (manual harvesting)

$\rightarrow$-Revenue per hectare

$\rightarrow$ Explicit costs + implicit costs (semi-mechanized)

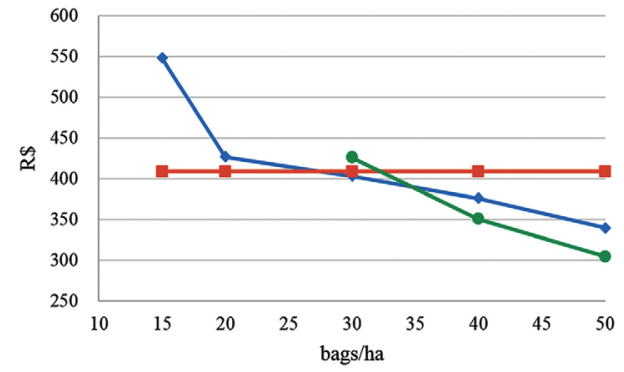

$\multimap$ Explicit costs + implicit costs (manual harvesting) - Revenue per hectare

$\rightarrow-$ Explicit costs + implicit costs (semi-mechanized)

GRAPH 1: Explicit costs and revenue per ha for different productivity levels (3rd year) A; Explicit and implicit costs and revenue per ha for different productivity levels (3rd year) B; Explicit costs and revenue per bag for different productivity levels (3rd year) $\mathrm{C}$ and Explicit and implicit costs and revenue per bag for different productivity levels (3rd year) D.

TABLE 2 - Production costs and revenues (3rd year) of 1 ha of arabica coffee at different yield levels and indicators of economic viability (during the whole production life cycle)

\begin{tabular}{lcccccccc}
\hline $\begin{array}{c}\text { Specification / } \\
\text { Productivity levels } \\
\text { (bags / ha) }\end{array}$ & $\mathbf{1 5}$ & $\mathbf{2 0}$ & $\mathbf{3 0}$ & $\mathbf{4 0}$ & $\mathbf{5 0}$ & $\mathbf{3 0}$ & $\mathbf{4 0}$ & $\mathbf{5 0}$ \\
\hline Inputs & $1,726.92$ & $2,012.92$ & $2,185.30$ & $2,988.78$ & $2,897.22$ & $4,007.88$ & $3,857.53$ & $3,765.97$ \\
Labor & $4,255.75$ & $4,205.00$ & $7,017.50$ & $8,756.00$ & $10,164.50$ & $5,877.50$ & $6,866.00$ & $7,524.50$ \\
Total direct costs & $5,982.67$ & $6,217.92$ & $9,202.80$ & $11,744.78$ & $13,061.72$ & $9,885.38$ & $10,723.53$ & $11,290.47$ \\
Crop depreciation & 545.93 & 578.14 & 796.81 & 945.91 & $1,187.16$ & 796.71 & 945.91 & $1,187.16$ \\
Depreciation & & & & & & & & \\
machines & 353.76 & 360.39 & 373.47 & 386.35 & 399.22 & 373.47 & 386.35 & 399.22 \\
Cost of land & 486.59 & 486.59 & 486.59 & 486.59 & 486.59 & 486.59 & 486.59 & 486.59 \\
Opportunity cost & 844.38 & 890.33 & $1,232.39$ & $1,466.15$ & $1,842.48$ & $1,232.25$ & $1,466.15$ & $1,842.48$ \\
Total cost & $8,213.34$ & $8,533.37$ & $12,092.06$ & $15,029.78$ & $16,977.18$ & $12,774.40$ & $14,008.53$ & $15,205.93$ \\
Total revenue & $6,127.50$ & $8,170.00$ & $12,255.00$ & $16,340.00$ & $20,425.00$ & $12,255.00$ & $16,340.00$ & $20,425.00$ \\
Net revenue & $-2,085.84$ & -363.37 & 162.94 & $1,310.22$ & $3,447.82$ & -519.40 & $2,331.47$ & $5,219.07$ \\
\hline NPV (8\%) & $-33,762.81$ & $-18,630.70$ & $-19,291.53$ & $-15,348.21$ & 763.23 & $-13,424.80$ & $-1,716.72$ & $21,411.12$ \\
IRR & - & - & - & - & $8.3 \%$ & - & $7.1 \%$ & $16.0 \%$ \\
\hline
\end{tabular}

Coffee Science, Lavras, v. 14, n. 2, p. 223 - 230, apr./jun. 2019 


\section{CONCLUSION}

The results show advantages of semimechanized harvest. At the level of 50 bags per hectare, the activity was profitable, considering an interest rate of $8 \%$. In manual harvesting the IRR was $8.3 \%$ and in the semi-mechanized harvest the IRR was $16 \%$. The evaluation reveals that costs are above revenue for farmers who produce near or below the state yield average. Public policies such as subsidized rural credit, for example, only reduce financial costs. However, they are not enough for farmers that produce at low yield levels to obtain profit. These producers should invest more, seeking higher yield levels and investments in new technologies, technical assistance and mechanization to have a return in the activity.

\section{ACKNOWLEDGEMENTS}

The authors would like to thank the Foundation for Research Support of the state of Espírito Santo - FAPES and Brazilian Agricultural Research Corporation - EMBRAPA.

\section{REFERENCES}

AMARASINGHE, U. A.; et. al. Toward sustainable coffee production in Vietnam: More coffee with less water. Agricultural Systems. v.136, p.96-105, 2015.

APARECIDO, L. E. O.; ROLIM, G. S.; SOUZA, P. S. Sensitivity of newly transplanted coffee plants to climatic conditions at altitudes of Minas Gerais, Brazil. Australian Journal of Crop Science, Queensland, v. 9, n. 2, p. 160-167, 2015.

APARECIDO, L. E. O. et. al. Agrometeorological Models for Forecasting Coffee Yield, Agronomy Journal, Madison, v.108, n.6, 2016.

ASSAF NETO, A.; LIMA, F. G. Curso de Administração Financeira.3. ed. São Paulo: Atlas, 2014.

BARBOSA, J. N. et. al. Coffee quality and its interactions with environmental factors in Minas Gerais, Brazil. Journal of Agricultural Science, Alberta, v. 4, n. 5, p. 181-190, 2012.

CÁRDENAS, E. L. M. et al. Development of a new striker for a portable coffee harvesting tool. Revista da Faculdade Nacional de Agronomia de Medellín, Medellín, v. 66, n. 2, p. 7071-7083, 2013.
CÁRDENAS, E. L. M.; TASCÓN, C. E. O.; MEJÍA, F. A. A portable device to assist in the harvest of coffee in Colombia. Revista da Faculdade Nacional de Agronomia de Medellín, Medellín, v. 68, n. 1, p. 7471-7479, 2015.

CARNIELLI, H. P.; SANTOS, J. G.; RAPOSO FH, F. L. Valores de terra nua nas diferentes Regiões do estado do Espírito Santo. Vitória: Cedagro, 2017. Disponível em: <http://www.cedagro.org.br/arquivos/ Valor_Terra_Nua_Resumo_2017.pdf $>$ Acesso em 20/02/2018.

CHIPANSHI, A. et al. Evaluation of the Integrated Canadian Crop Yield Forecaster (ICCYF) model for in-season prediction of crop yield across the Canadian agricultural landscape. Agricultural and Forest Meteorology. v.206, p.137-150. 2015.

COMPANHIA NACIONAL DE ABASTECIMENTO. Custos de produção agrícola: a metodologia da Conab. Brasília: Conab, 2010. Disponível em: <http://www.conab.gov.br/OlalaCMS/uploads/ ivos/0086a569bafb14cebf87bd111936e115..pdf> Acesso em 20/02/2018.

COMPANHIA NACIONAL DE ABASTECIMENTO. A cultura do café: análise dos custos de produção e da rentabilidade nos anos safra 2008 a 2017. Compêndio de estudos CONAB v. 12, Brasília, 2017.

COMPANHIA NACIONAL DE ABASTECIMENTO. Série histórica das safras.Disponível em: <https:// www.conab.gov.br/info-agro/safras/serie-historicadas-safras> Acesso em: 15/01/2018.

CUNHA, J. P. B. et al. Análise técnica e econômica de diferentes sistemas de transplantio de café (Coffea arabica L.). Coffee Science, Lavras, v. 10, n. 3, p. 289 - 297, jul./set. 2015.

CUNHA, J. P. B. et al. G. Estudo técnico e econômico de diferentes operações mecanizadas na cafeicultura. Coffee Science, Lavras, v. 11, n. 1, p. 87 - 96, jan./mar. $2016 a$.

CUNHA, J. P. B. et al. Viabilidade técnica e econômica de diferentes sistemas de colheita do café. Coffee Science, Lavras, v. 11, n. 3, p. 416 - 425, jul./set. 2016 b.

FERNANDES, A. L. T. et al. Redução da adubação mineral do cafeeiro arábica com a utilização de palha de café. Coffee Science, Lavras, v. 8, n. 3, p. 324-336, jul./set. 2013. 
FORTES, P. H. O. Custos de produção de café com relação ao tipo de produção: manual, semimecanizado e mecanizado. Monografia de conclusão de curso de agronomia. Universidade Federal de Lavras. 2017.

GALEANO, E. A. V. et al. Síntese da produção agropecuária do Espírito Santo 2014/2015. Vitória: Instituto Capixaba de Pesquisa, Assistência Técnica e Extensão Rural - Incaper, 2017 (Documento 247). Disponível em: <http://biblioteca.incaper.es.gov.br/ digital/bitstream/item/2699/1/BRT-sintese-2014-2015final.pdf>. Acesso em 01/03/2018.

GALEANO, E. A. V. et al. O. Síntese da produção agropecuária do Espírito Santo 2016/2017. Vitória: Instituto Capixaba de Pesquisa, Assistência Técnica e Extensão Rural - Incaper. Documentos, 257, Vitória, ES: Incaper, 2018. Disponível em: <https://biblioteca. incaper.es.gov.br/digital/bitstream/123456789/3271/1/ Sintese-agrpecuaria2016-2017.pdf $>$ Acesso em: $15 / 01 / 19$.

GITMAN, L. J. Princípios de administração financeira. 10. ed. São Paulo: Pearson Addison Wesley, 2010. 800p.

IBGE. INSTITUTO BRASILEIRO DE GEOGRAFIA E ESTATÍSTICA. Grupo de Coordenação de Estatísticas Agropecuárias - GCEA/IBGE, Diretoria de Pesquisas, Coordenação de Agropecuária, Levantamento Sistemático da Produção Agrícola, Vitória-ES, dezembro de 2018. Relatório de pesquisa.

Produção Agrícola Municipal - PAM. Sistema IBGE de Recuperação Automática de dados - SIDRA, IBGE-PAM, 2000 a 2017 Disponível em: < http://www2.sidra.ibge.gov.br/bda/acervo/acervo9. asp? $\mathrm{e}=\mathrm{c} \& \mathrm{p}=\mathrm{PA} \& \mathrm{z}=\mathrm{t} \& \mathrm{o}=11>$. Acesso em: 29/03/2018.

JASPER, S. P.; SILVA, R. A. P. Estudo comparativo do custo operacional horário da mecanização agrícola utilizando duas metodologias para o estado de São Paulo. Nucleus, Ituverava, v. 10, n. 2, p. 119-126, 2013.

LANNA, G. B. M., REIS, R. P. Influência da mecanização da colheita na viabilidade econômico financeira da cafeicultura no sul de Minas Gerais. Coffee Science, Lavras, v. 7, n. 2, 2012.

MANKIW, N. G. Princípios de Microeconomia. 6. Ed. Cengage: São Paulo, 2014.

MATIELlO, J. B. et al. Cultura do café no Brasil: manual de recomendações. São Paulo: Faturama Editora, 2016.
MATIELLO, J. B. Custos da produção de café estão em alta. Folha técnica 407. Fundação Procafé. Disponível em:http://fundacaoprocafe.com.br/sites/default/ files/publicacoes/pdf/folhas/Folha\%20407\%20-\%20 Custos\%20de\%20produ\%C3\%A7\%C3\%A3o\%20 de\%20caf\%C3\%A9\%20est\%C3\%A3o\%20altos.pdf. Acesso em 20/03/2018.

MEJÍA, F. A.; TASCÓN, C. E. O.; URIBE, J. R. S. Evaluation of mechanical beaters in coffee harvesting. Revista da Faculdade Nacional de Agronomia de Medellín, Medellín, v. 66, n. 1, p. 6919-6928, 2013.

MINISTÉRIO DO TRABALHO E DO EMPREGO - TEM. Relação Anual de Informações Sociais RAIS. Disponível em: http://bi.mte.gov.br/bgcaged/ inicial.php. Acesso em 27 nov. 2017.

OLIVEIRA, E.; SILVA, F. M.; SOUZA, Z. M.; FIGUEIREDO, C. A. P. Influência da colheita mecanizada na produção cafeeira. Ciência Rural, Santa Maria, v. 37, n. 5, 2007.

PIACENTINI, L. et al. Software para estimativa do custo operacional de máquinas agrícolas MAQCONTROL. Revista Engenharia Agrícola, Jaboticabal, v. 32, n. 3, p. $609-623,2012$.

PINTO, V.M.; REICHARDT, K.; DAM, J.V.; LIER, Q.J.V.; BRUNO, I.P.; DURIGON, A.; DOURADO-NETO, D.; BORTOLOTTO, R.P. Deep drainage modeling for a fertigated coffee plantation in the Brazilian savanna. Agricultural Water Management.v.148, p.130-140, 2015.

SANTINATO, F. et al. Análise quali-quantitativa da operação de colheita mecanizada de café em duas safras. Coffee Science, Lavras, v. 9, n. 4, p. 495 - 505, out./dez. 2014.

SANTINATO, F. et al . Mechanical harvesting of coffee in high slope. Rev. Caatinga, Mossoró, v. 29, n. 3, p. 685-691, set. 2016 .

SANTOS, G. J.; SEGATTI, S.; MARION, J. C. Administração de custos na agropecuária. 4. ed. São Paulo: Atlas, 2009. 168 p.

SANTOS, V. E.; GOMES, M. T. M.; GOMES, M. F. M. Estimativa da elasticidade-renda do consumo de café na região sudeste do brasil. Revista de Economia e Agronegócio, Viçosa, v. 3, n. 4, p. 537-558, 2015.

SANTOS, R. V. M. et al. Pós-café: um sistema de apoio a decisão para o cálculo do custo da pós-colheita do café. Coffee Science, Lavras, v. 8, p. 439-449, 2013. 
SANTOS, R. V. M.; VIEIRA, H. D.; BORÉM, F. M. Desenvolvimento de cenários utilizando um sistema de apoio à decisão para análise de custos da fase de póscolheita do café. Coffee Science, Lavras, v. 10, n. 4, p. 445 - 454, o ut./dez. 2015.

SANTOS, R. V. M. et al. Estatística multivariada aplicada em dados de custos da fase de pós-colheita do café. Coffee Science, Lavras, v. 12, n. 2, p. 223 - 230, abr./jun. 2017.

SILVA, O. M. da; LEITE, C A. M. Competitividade e custo do café no Brasil e no exterior. In: ZAMBOLIN, L. (Ed.). Café: produtividade, qualidade $e$ sustentabilidade. Viçosa, MG: UFV, p. 27-50. 2000.
SILVA, F. M. da et al. Viabilidade técnica e econômica da colheita mecanizada do café. Revista Visão Agrícola, Piracicaba, n. 13, p. 98-101, 2013.

SILVA, R. P. et al. Qualidade das operações de preparo reduzido do solo e transplantio mecanizado de mudas de café. Coffee Science, Lavras, v. 9, n. 1, p. 51-60, 2014.

SOUZA, G. S. et al. Colheita mecanizada de café conilon. In: FERRÃO et. al., Café Conilon. 2 ed. $2^{\mathrm{a}}$. Reimpressão, Vitória: Incaper, 2017.

TAVARES, T. O. et al. Qualidade do recolhimento mecanizado do café. Coffee Science, Lavras, v. 10, n.4, p. 455-463, 2015. 